体力科学 (2003) $52 \mathrm{Suppl,} \mathrm{141} \mathrm{148}$

膝関節伸展トルクおよび脚伸展パワーにおける年齢差および性差

\author{
立正 伸 ${ }^{1)}$ 牛山潤一1) 宮谷昌枝 ${ }^{1)}$

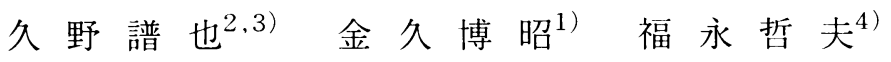

\section{AGE- AND BENDER RELATED DIFFERENCES IN KNEE EXTENSION TORQUE AND LAG EXTENSION POWER}

\author{
Masanobu Tachi, Jinichi Ushiyama, Masae Miyatani, Silinya Kuno, \\ Hiroaki Kanehisa and Tetsuo Fukunaga
}

\begin{abstract}
This study was aimed to investigate the influences of age and gender on isometric muscle torque and explosive muscle power output with reference to muscle volume. A total of 177 healthy subjects of both genders were divided into four groups according to their age and gender : 46 young men $(22.0 \pm 3.2 \mathrm{yrs}), 43$ young women $(22.7 \pm 3.3 \mathrm{yrs}), 46$ elderly men $(71.2 \pm 4.3 \mathrm{yrs})$ and 42 elderly women $(72.7 \pm 4.5 \mathrm{yrs})$. The maximal voluntary isometric knee extension torque of the right leg (hip and knee angle at 90 degrees) and the power of bilateral leg extension in sitting position were measured. The ratios of both torque and power to muscle volume, estimated using ultrasonograph measurement, was calculated (torque/MV and power/MV respectively). Torque was significantly less among the elderly than among the young for both genders, and among women than among the men for both age groups. Significant age-related differences were evident even in terms of torque $\mathrm{MV}$, but the corresponding differences between men and women disappeared. On the other hand. power/MV showed significant age- and gender-related differences, and the age-related difference was larger than that for torque/MV. These results suggest that age- and gender-related differences in power are more noticeable than differences in torque and that these differences are not simply explained by differences in muscle volume.
\end{abstract}

(Jpn. J. Phys. Fitness Sports Med. 2003, 52 Suppl : 141 148)

key word : torque, power, muscle volume, aging effect, gender-related difference

\section{目的}

等尺性最大筋力における加齢の影響は50〜60歳 を境に顕著なものとなり, 特に下肢筋群において その低下は著しい ${ }^{1-3)}$. 動的な筋活動における 最大筋力についてもその傾向は同様であり, 等速 性運動における短縮性および伸張性の最大筋力も 50～60歳以降に顕著に低下寸る ${ }^{4,5)}$. 一方, Bas- sey et al. ${ }^{6)}$ は, 高齢者を被験者とした研究に打い て, 脚伸展パワーと椅子からの立ち上がり, 階段 昇降および歩行の各成績との間に有意な相関関係 を認め, 高齢者の日常生活に扔ける連動能力を考 えるうえで脚伸展パワーの测定が有効であること を指摘している。しかし，動的なパワーにおける 加齢变化という視点から筋機能への加齢の影響を 捉えた研究は少ない ${ }^{7.8)}$.その中で, 15〜72歳の

\footnotetext{
${ }^{1)}$ 東京大学大学院総合文化研究科生命環境科学系 Department of Life Sciences (Sports Sciences). University of 下 153-8902 東京都目黑区駒場3-8-1

2) 筑波大学体育科学系 于305-8574 茨城県つくば市天王台1-1-1

3) 筑波大学:先端学際領域センター テ305-8574 茨城県つくば串天王台1-1-1

4) 早稲田大学人間科学部スポーツ科学科 于359-1192 埼玉県所沢市三ヶ島2-579-15

\author{
Department of Life Sciences (Sports Sciences). University of
Tokyo, Komaba 3-8-1, Meguro-Ku, Tokyo, 153-8505. Japan \\ Institute of Health and Sport Science, University of Tsukuba. \\ 1-1-1. Tennoudai, Tsukuba, Ibaraki, 305-8574. Japan \\ Center for Tsukuba Advanced Research Alliance. Lniversity of \\ Tsukuba, 1-1-1, Tennoudai, Tsukuba. Ibaraki. 305-8577. Japan \\ School of Human Science. Waseda University, 2-579-15.
} Mikajima, Tokorozawa, Saitama, 359-1192. Japan
} 
男子を対象にした川初 ${ }^{7)}$ の報告によると, 膝関節 伸展の等尺性最大筋力および最大パワーは, とも に40歳代から50歳代以降に低下が始まり，20～24 歳群の平均值に対する 65 歳以上群の平均値の割合 は，等尺性最大筋力で $69 \%$, 最大パワーで $68 \%$ と その加齢低下はほほ同程度である。このような結 果は, パワーも筋力と同様な加齢変化を遂げるこ とを意味する。

静的および動的運動における最大筋力の加齢に ともなう低下は主に筋量の減少が原因だといわれ ている. 先行研究においては, 筋量の評価指標と して筋断面積, 筋体積, 筋重量, 除脂肪組織量, あるいは体重などを用い，単位筋量当たりの筋力 もまた加齢により低下することが示されてい $3^{8 \sim 12)}$. その原因として, 運動中の筋の動員量, 筋線維組成, 収縮要素の質などの変化が考えられ ている ${ }^{4.13 .14)}$. しかし，単位筋量当たりの筋力 の加齢变化における性差については，一致した見 解が得られていない. 例えば, Akima et al. ${ }^{11)}$ は, 20８4歳の男女を対象とし，単位筋断面積当たり の等尺性最大筋力と年齢の関係を検討したとこ ろ, 男性では負の相関関係が認められたが, 女性 では有意な相関関係は存在しないと報告してい る.一方，18８7歳の女性を対象にした Madsen et al. ${ }^{10)}$ の結果では, DEXA 法により測定した下 肢除脂肪組織量で規格化された等速性最大膝関節 伸展力は年齢と負の相関関係にある。一方, 両脚 での踏み込み動作による脚伸展パワーを10歳代か ら80歳代までの男女を対象に測定した平野たち8) の結果では, 体重当たりのパワーは男女とも20歳 代から80歳代にかけてほほ直線的に低下し，その 低下率は女性より男性の方が大きい。このような 報告間の違いの要因は不明であるが，上記の研究 結果は, 仮に同一被験者に対し筋力およびパワー を測定した場合，それらの単位筋量当たりの值に おける加齢変化には, 測定間で違いが存在すると 同時に, 男女差も含まれることを示唆するものと いえる。

本研究は, 20～30歳および65～83歳の男女を対 象に, 筋量の評価指標として超音波法により大腿 前部(膝関節伸展筋群)の筋体積を推定するととも
に, 最大等尺性膝関節伸展トルク, 踏み込み動作 での脚伸展パワーを測定し，等尺性トルクおよび 動的パワーの加齢変化およびその性差について, 筋量との関係から検討することを目的とした。

\section{方法}

\section{A . 被験者}

20～30歳(若齢群)および65８3歳 (高齢群)の男 女を被験者とした。被験者は年齢群および性別ご とに，それぞれ若齢男性 (YM) 群, 若齢女性 (YF) 群, 高齢男性 (OM) 群, 高齡女性(OF) 群の 4 群に 分類した. 被験者数は YM 群46名, YF 群 43 名, OM 群46名, OF 群42名の計177名であった. 被験 者の身体特性は表 1 に記した。測定に際し, 被験 者には測定の目的, 手順, 安全性について十分な 説明を行い, 測定参加への同意書を得た。

\section{B. 測定項目}

\section{1）大腿長および筋厚}

大腿長は大転子から膝関節裂隙までの長さと し，スチール製のメジャーを用いて測定点間の最 短距離を計測した。大腿前部 (膝関節伸展筋群)の 筋厚は, Bモード超音波装置 (SSD-500, ALOKA， 東京, 日本)を用いて測定した。測定に用いた超 音波装置の超音波発振周波数は $5 \mathrm{MHz}$ とした。 測定時における被験者の姿勢は安静立位であり, 測定は右脚について実施した。筋厚の測定部位は 大腿長の遠位 $50 \%$ 部位の大腿直筋上とし, 油性マ ジックインクを用いて印をつけた後, 測定を実施 した，超音波装置によって得られた画像を元に， 皮下脂肪組織と筋組織との境界面から大腿骨まで の矢状方向の距離を $0.5 \mathrm{~mm}$ 単位で計測し, 大腿 前部の筋厚とした。

\section{2) 筋体積の推定}

男性の被験者については, Miyatani et al. ${ }^{15)} の$ 推定式を用い, 大腿長および大腿前部の筋厚から 膝関節伸展筋群の筋体積を推定した。一方, Miyatani et al. ${ }^{15)}$ において報告されている推定式 は男性を対象としたものであり，女性を対象とし た場合の推定式は提示されていない。そこで本研 究では, Miyatani et al. ${ }^{15)}$ と同様な方法により, 
測定対象者とは別の女性51名(年齢，24８1歳)か ら得られた超音波および MRI 測定デー夕に基づ き女性の筋体積推定式を作成した。以下に本研究 で用いた男女の推定式を示した。

男性: $\mathrm{MV}=\left[\pi \times(\mathrm{MT} / 2)^{2} \times \mathrm{L}\right]$

$\times 1.1176+663.040($ Miyatani et al.)

女性: MV $=\left[\pi \times(\mathrm{MT} / 2)^{2} \times \mathrm{L}\right]$

$$
\times 0.7839+610.948
$$

$(\mathrm{MV}$, 筋体積; $\mathrm{MT}$, 筋厚 ; $\mathrm{L}$, 体肢長 ; $\pi, 3.14$ )

なお，上記の式によって得られる筋体積推定値 とMRI法によって測定した筋体積との差から計算 した推定值の標準誤差は, 男性 $173.7 \mathrm{~cm}^{3}$ (10.5\%), 女性 $105.6 \mathrm{~cm}^{3}(11.1 \%)$ であった。

3）最大等尺性膝関節伸展卜ルク

膝関節伸展トルクは, 特別に作成された膝関節 トルク計 (model KND-005, VINE 社, 東京, 日本) を用いて測定した。測定姿勢は椅座位であり，股 関節および膝関節角度は90度に固定し, 測定は右 脚についてのみ実施した。測定に先立ち, 被験者 は十分な準備運動と, 最大下努力での筋力発揮を 行った。本測定では, 約 3 秒間の等尺性最大随意 筋収縮を, 約 1 分間の休息を間にはさみ 2 回ずつ 行わせた。測定信号は 12 bit A/D 变換器 (Power Lab/8SP, AD Instruments, Australia) でデジ夕 ル変換した後, サンプリング周波数 $100 \mathrm{~Hz}$ でサ ンプリングし，コンピュータに取り込んだ。2 回 の試行それぞれについてトルクのピーク値を算出 し，そのうち大きい方の值を最大等尺性膝関節伸 展トルクとした。また，得られた最大等尺性膝関 節伸展トルクを膝関節伸展筋群の筋体積で除すこ とにより,単位筋体積当たりのトルクを算出した。

4）脚伸展パワー

脚伸展パワーの測定は, ブレーキ負荷を応用し た脚伸展パワー測定マシン(アネロプレス 3500 , COMBI, 東京, 日本) を用いて, 平野たち ${ }^{8)}$ と同 様の手順により測定した. 測定姿勢は椅座位とし, 膝関節角度 90 度の状態で, 腰部を測定マシンの座 面に，両足をフットプレート上にそれぞれベルト で固定した，負荷值は被験者の体重と等しいもの とし，各試行間に15秒間の間隔をおきながら，全
力での脚伸展動作を計 5 回行った. 分析には 5 回 の試行の最大值を用いた。また, 得られた脚伸展 パワーの最大值を膝関節伸展筋群の筋体積で除す ことにより，単位筋体積当たりの脚伸展パワーを 算出した.

\section{C. データ解析}

統計量は平均値土標準偏差で示した。各変数の 性差および年齢差を検討するため, 繰り返しなし の二元配置の分散分析を行った。性別，年龄の間 に交互作用が認められた場合には, 繰り返しなし の一元配置の分散分析を用い, 各群ごとの比較を 行った。分散分析で有意差が認められた場合には post-hoc 分析として, Scheffe の多重比較法を用 いた。 それぞれの統計量について，若齢群に対す る高齢群の割合を百分率で求め，それを $100 \%$ か ら引くことによって得られる值を，加齢による低 下率として算出した.また,筋体積と脚伸展パワー との間の対応関係を調べるために，各群ごとに Pearsonの相関分析を行った。 それぞれの統計量 における加㱓および性別間での差および筋体積と 脚伸展パワーの相関係数 $(\mathrm{r})$ の有意限界は確率水 準 $1 \%$ とした。

\section{結果}

\section{A . 推定筋体積}

大腿前部の筋厚は, 男女とも若齢群 ( YM, 53.5 $\pm 5.4 \mathrm{~mm} ; \mathrm{YF}, 46.6 \pm 7.0 \mathrm{~mm}$ ) が高齢群 (OM, $41.0 \pm 4.7 \mathrm{~mm} ; \mathrm{OF}, 37.7 \pm 7.2 \mathrm{~mm})$ より有意に 大きく，両年齢群とも男性の方が女性より有意に 大きかった (Table 1). 各被験者群の膝関節伸展 筋群の推定筋体積は, YM 群1683.2 $214.7 \mathrm{~cm}^{3}$, YF 群 $1113.6 \pm 153.1 \mathrm{~cm}^{3}$, OM 群 $1208.7 \pm 125.2$ $\mathrm{cm}^{3}$ および OF 群 $919.4 \pm 133.2 \mathrm{~cm}^{3}$ となり, 筋 厚と同様に有意な年齢差および性差が存在した (Fig. 1).

\section{B． 膝関節伸展トルクおよび脚伸展パワー}

最大膝関節伸展トルクは, 男女とも若齢群 (YM, $174.4 \pm 50.0 \mathrm{Nm} ; \mathrm{YF}, 96.8 \pm 24.7 \mathrm{Nm}$ ) が 高龄群 $(\mathrm{OM}, 98.5 \pm 34.6 \mathrm{Nm}$; OF, $66.9 \pm 21.1$ 
Table 1. Physical characteristics of each subject groups.

\begin{tabular}{c|cccc}
\hline Variables & YF & YM & OF & OM \\
\hline Number & 43 & 46 & 42 & 46 \\
Age (yrs) & $22.7 \pm 3.3$ & $22.0 \pm 3.2$ & $72.7 \pm 4.5$ & $71.2 \pm 4.3$ \\
Height $(\mathrm{cm})$ & $158.8 \pm 5.7 \#$ & $172.4 \pm 5.8^{*} \#$ & $149.6 \pm 5.1$ & $161.7 \pm 5.5^{*}$ \\
Body mass $(\mathrm{kg})$ & $51.9 \pm 6.1$ & $65.9 \pm 9.0^{*} \#$ & $52.8 \pm 7.3$ & $59.0 \pm 6.5^{*}$ \\
Muscle thickness $(\mathrm{mm})$ & $46.6 \pm 7.0 \#$ & $53.5 \pm 5.4^{*} \#$ & $37.7 \pm 7.2$ & $41.0 \pm 4.7^{*}$ \\
Thigh length (cm) & $36.8 \pm 1.7 \#$ & $40.2 \pm 2.0^{*} \#$ & $33.9 \pm 1.7$ & $36.5 \pm 1.9^{*}$ \\
\hline
\end{tabular}

YF, young female group ; YM, young male group ; OF ; old female group ; OM ; old male group. Values are means $\pm \mathrm{SD} .{ }^{*}$, significantly larger in male than in female within the same age groups: \# , significantly larger in young than in old within the same gender.

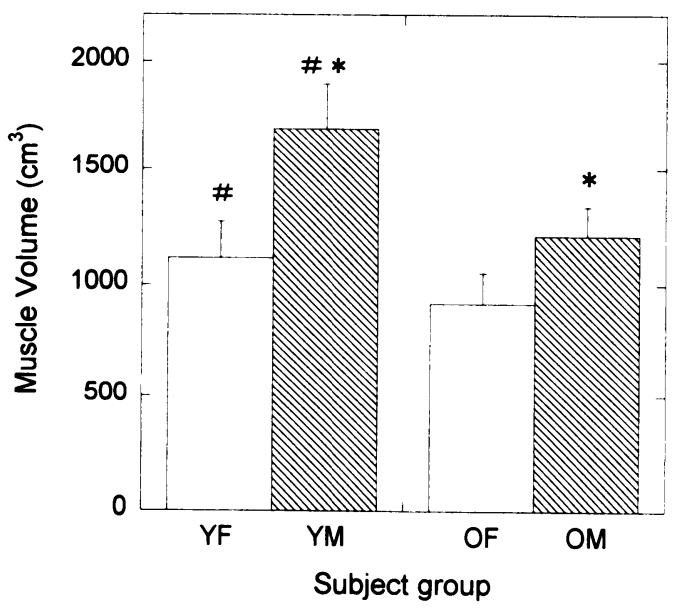

Fig. 1. Comparison between subject groups on esti. mated muscle volume. ${ }^{*}$, significantly larger in male than in female within the same age groups ; \# , significantly larger in young than in old within the same gender.

$\mathrm{Nm}$ ）より，また，両年齢群とも男性の方が女性 よりそれぞれ有意に大きな值を示した(Fig. 2 A). 男女両群の加齢に伴うトルクの低下率は男性が 43.5\%，女性が30.8\%と男性の方が大きかった。 また, 男性に対する女性のトルクの比率は, 若齡 群が55.5\%, 高齢群が $67.9 \%$ あり，加齢により 性差は小さくなる傾向にあった.

最大脚伸展パワーもトルクと同様に, 男女とも

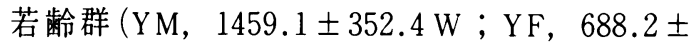
$246.9 \mathrm{~W})$ が高齢群 $(\mathrm{OM}, 707.1 \pm 219.7 \mathrm{~W}$; OF, $333.8 \pm 185.0 \mathrm{~W})$ より，また，両年齢群とも男性 の方が女性よりそれぞれ有意に高值であった (Fig. 2B). しかし, 男女両群とも加齢に伴うパ ワーの低下率は $51.5 \%$ と同等であり，男性に対す
る女性のパワーの比率は，両年齢群ともに $47.2 \%$ であった。

\section{C．筋体積当たりの膝関節伸展トルクおよび脚 伸展パワー}

単位筋体積当たりのトルクは，男女とも若龃群 (YM, $0.104 \pm 0.027 \mathrm{Nm} / \mathrm{cm}^{3}$; YF, $0.087 \pm 0.021$ $\mathrm{Nm} / \mathrm{cm}^{3}$ ) が高歯群 (OM, $0.081 \pm 0.028 \mathrm{Nm} / \mathrm{cm}^{3}$; $\left.\mathrm{OF}, 0.072 \pm 0.019 \mathrm{Nm} / \mathrm{cm}^{3}\right)$ より有意に大きく,

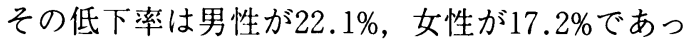
た。しかし，両年齢群とも有意な性差はみられな かった(Fig. $3 \mathrm{~A})$.

一方, 単位筋体積当たりのパワーは, 男女とも 若齢群 (YM, $0.87 \pm 0.20 \mathrm{~W} / \mathrm{cm}^{3} ; \mathrm{YF}, 0.61 \pm 0.17$ $\mathrm{W} / \mathrm{cm} 3)$ が高齢群 (OM, 0.58土0.17 W/cm3 ; OF, $\left.0.36 \pm 0.17 \mathrm{~W} / \mathrm{cm}^{3}\right)$ より有意に大きく，その低 下率は男性が $33.3 \%$ ，女性が41.0\%であり，筋体 積やトルクとは逆に女性の低下率が大きかった。 また，両年齢群において，男性の方が女性より有 意に高い值を示し, 男性群に対する女性群の比率 は，若齢群が $70.1 \%$ ，高齢群が $62.1 \%$ あったた (Fig. 3 B).

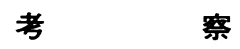

本研究では, 筋量の指標として筋体積を用い た. Fukunaga et al. ${ }^{16)}$ によると, トルクは筋断面 積よりも筋体積との間に強い相関関係を示す。一 方, パワーはカ $\times$ 速度であり, 生理学的筋断面積 が筋の発揮張力を ${ }^{17)}$, 筋線維長が筋線維の収縮 速度を反映する ${ }^{18)}$. 腓腹筋内側頭を対象として, 筋線維長が筋長と比例するかどうかを調べた大場 
A
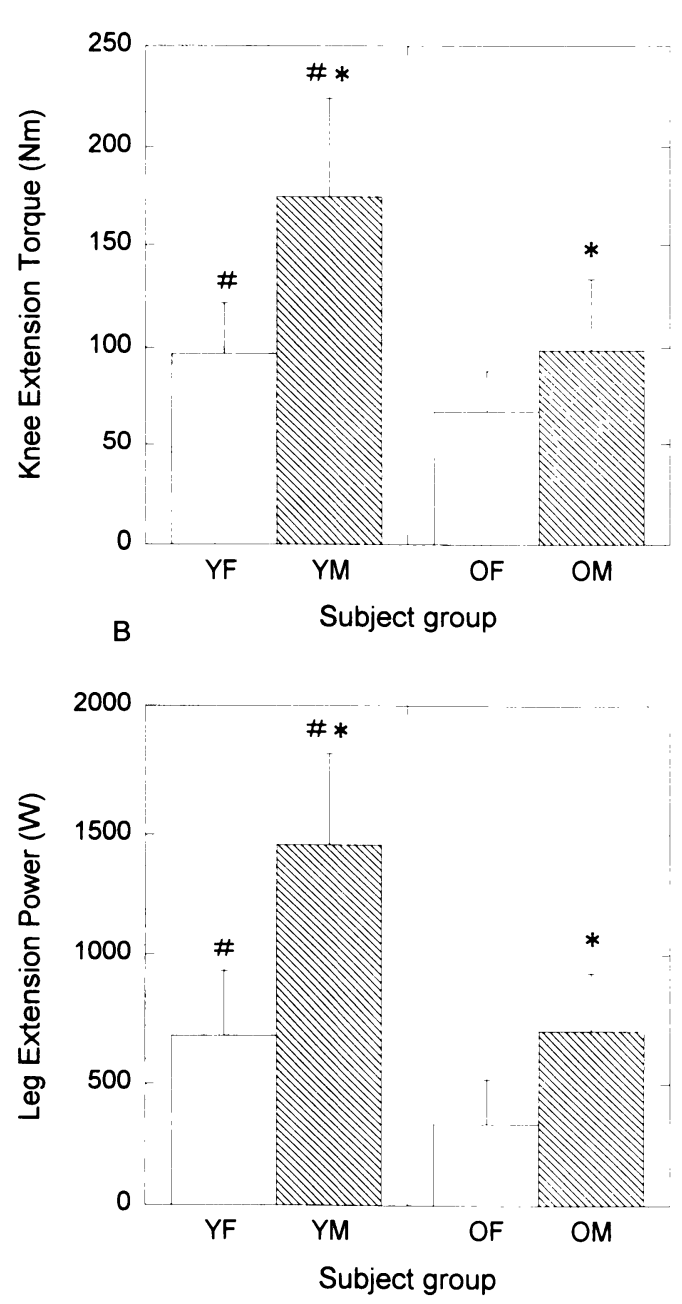

Fig. 2. Comparison between subject groups on $\max$ imum knee extension torque (A) and maximum leg extension power (B). The meanings of the sym. bols $\left(*,{ }^{*}\right)$ are the same with Fig. 1.

たち ${ }^{19)}$ の結果では，筋長と筋束長 (筋線維長) と の間に有意な相関関係があり，筋長と筋束長の比 に性差はないとされている。そのため筋断面積 $\times$ 筋長,つまり筋体積でパワーを割ることによって， 筋量当たりのパワーを算出することは妥当である と考えられる。また，筋量当たりの両脚の脚伸展 パワーを評価するために，今回，右脚のみの膝関 節伸展筋群体積を用いた。脚伸展パワーは膝関節 伸展筋群だけでなく股関節伸展筋群も使用すると 考えられる。ささらに, 両脚の力発揮では両側性機
A
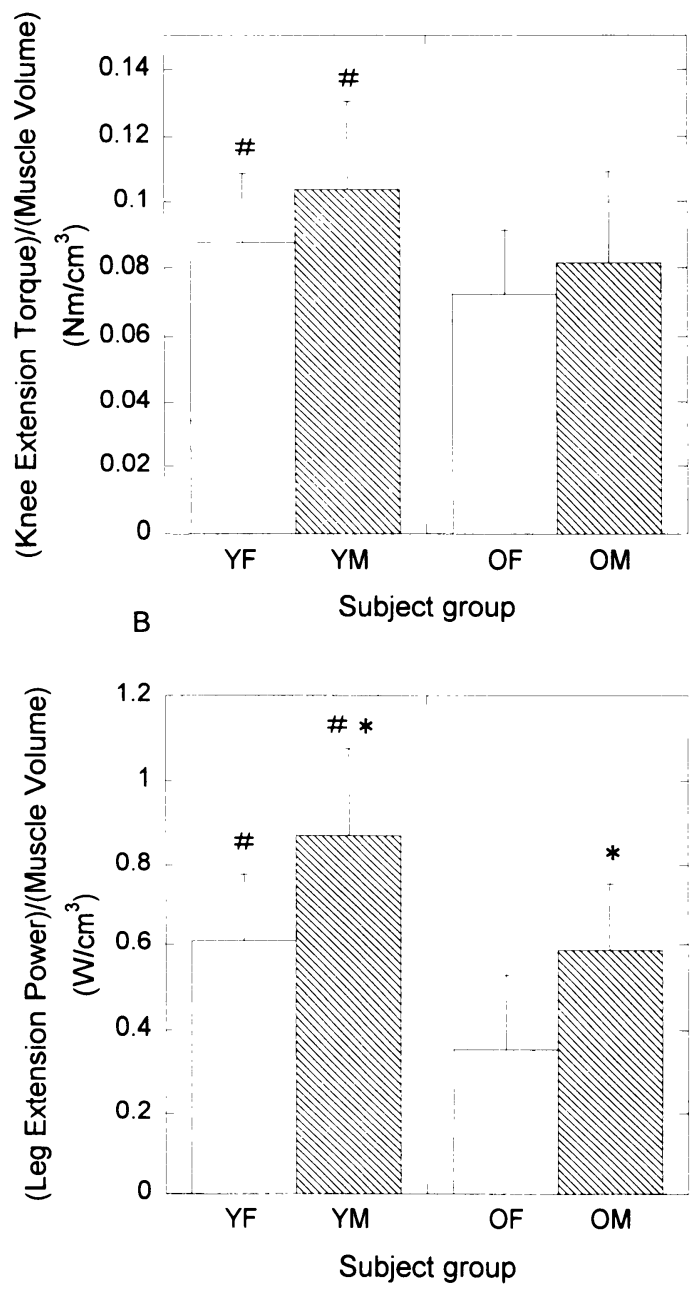

Fig. 3. Comparison between subject groups on maximum knee extension torque $(\mathrm{A})$ and maximum leg extension power (B), divided by muscle volume. The meanings of the symbols $(*, \#)$ are the same with Fig. 1.

能低下が見られるため，左右いずれかの脚での力 発揮能力を反映しない可能性も考えられる。しか し, Alkner et al. ${ }^{20)}$ の結果によると，片脚での等 尺性の脚伸展および膝関節伸展を膝関節角度 90 度 で行ったとき，発揮張力と大腿四頭筋の電気的活 動の関係は闭様式間で同様である。また，短縮性 の両脚での膝関節伸展において，両側の滕関節伸 展筋群の動員には年齢差および性差は存在しな $\omega^{21)}$.これら 2 つの先行研究の結果は, 単位筋 
量当りの脚伸展パワーおよび膝関節伸展トルクを 算出するにあたり，筋量の評価指標として片側の みの膝関節伸展筋群体積を用いることの妥当性を 指摘するものと考えられる。

トルクは，筋体積当たりの值でみても，その年 齢差は男女とも有意なものであった。この結果は， 高齢者は若齢者に比べ単位筋量当たりの筋力が低 いとする先行研究 ${ }^{9-12)}$ と一致する。一方，同年 齢群どうしの男女を比較すると，単位筋体積当た りのトルクには有意な性差がなかった。先行研

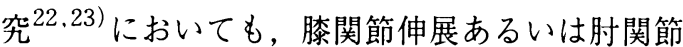
屈曲といった単関節動作における筋力の性差は主 に筋量の差に起因し，単位筋断面積当たりの筋力 に性差は存在しないといわれている.したがって， トルクにおける年齢差には，type II 線維の選択 的萎縮 ${ }^{13,14)}$ あるいは固有筋力の低下 ${ }^{4)}$ など筋量 以外の要因も含まれると考えられるが，その性差 は年齢に関係なく筋量における差に依存したもの であるといえる。

パワーは男女とも高齢群の方が若齢群より有意 に低い值を示した。本研究と同一の手順によりパ ワーを測定した平野たち ${ }^{8)}$ の結果によれば，本研 究の若齢群被験者の平均年齢に相当する30歳未満 の体重当たりのパワーは男子で $22.7 \mathrm{~W} / \mathrm{kg}$ ，女 子で $14.7 \mathrm{~W} / \mathrm{kg}$ である。また，高齢群の被験者 に相当する70歳代の体重当たりのパワーは男子で $10.0 \mathrm{~W} / \mathrm{kg}$ ，女子で $7.2 \mathrm{~W} / \mathrm{kg}$ である。これらは 本研究の若齢群 $(\mathrm{YM}, 22.3 \pm 5.2 \mathrm{~W} / \mathrm{kg} ; \mathrm{YF}, 13.1$ $\pm 3.9 \mathrm{~W} / \mathrm{kg})$ および高齢群 $(\mathrm{OM}, 12.0 \pm 3.36$ $\mathrm{W} / \mathrm{kg} ; \mathrm{OF}, 6.3 \pm 3.3 \mathrm{~W} / \mathrm{kg}$ )の各平均值とほほ 同じであり，年齢の推移に伴うパワーの低下率と いう点では, 本研究の結果と平野たち ${ }^{8)}$ のそれと はほほ一致している。また，パワーと同様に，単 位筋体積当たりのパワーにも加齢による低下がみ られ，その年齢差は単位筋体積当たりのトルクに おけるものよりも大きかった. Hakkinen et al. ${ }^{24)}$ は，定期的に運動を実施している女性に対する横 断的な観察結果から，単位筋断面積当たりの膝関 節伸展力に加齢の影響は認められないという結果 を得ている。しかし, 同じ対象において, 力発揮 速度には加齢の影響が存在し，高齢者ほどその
值は低い ${ }^{24)}$. 筋力と type II 線維の量および割合 との相関関係は, 等尺性の力発揮では明確ではな いものの ${ }^{25)}$, 高速度での筋力ほど強まる ${ }^{26)}$ 。一 方, type II 線維は加齢により選択的に萎縮す $3^{13,14)}$. したがって，最大パワー発揮のような 素早い動的な力発揮では，加齢による type II 線 維の萎縮による影響を静的な筋力発揮より大きく 受けると考えられ，そのことが，筋力以上に加齢 に伴うパワー低下を大きくしていると予想される。

また，本研究においての興味深い結果は，単位 筋体積当たりのパワーは，年齢に関係なく男性の 方が女性より有意に高值であったことである，先 述のように, 膝関節伸展あるいは肘関節屈曲とい った単関節動作における筋力の性差は，主に筋量 における差に起因し，単位筋断面積当たりの筋力 に性差は存在しない22,23). しかし, 体育専攻学 生を対象とした Ryushi et al. ${ }^{27)}$ の報告によると, 本研究におけるパワー測定と同様な姿勢により, 瞬発的に最大等尺性溙関節伸展を実施した際の力 発揮速度は，男子が女子より有意に高い。このよ うな力発揮速度の男女間での差異は, 単位筋体積 当たりのパワーに観察された男女差を説明する要 因になると考えられる，さらに，本研究では脚伸 展パワーという多関節運動のパワーを膝関節伸展

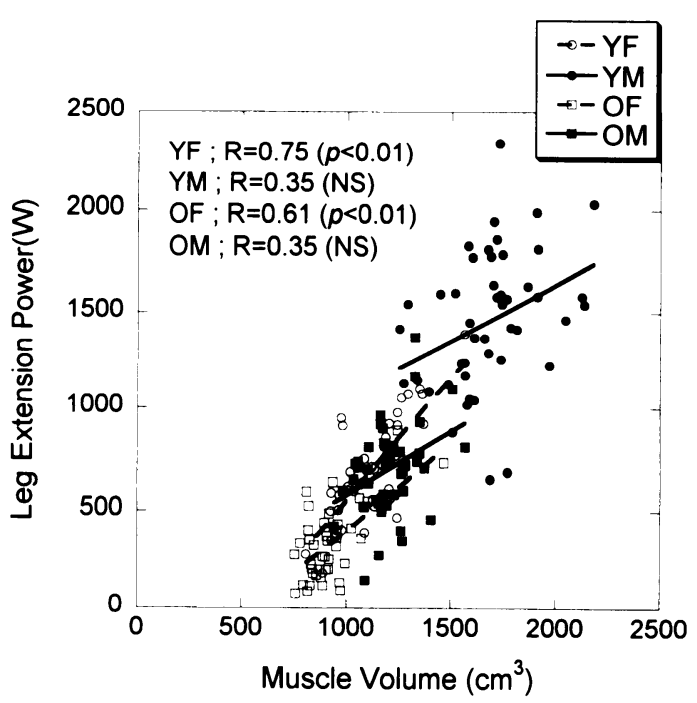

Fig. 4. Relationship between muscle volume and maximum leg extension power. 
筋群の単位筋体積当たりで検討した。それぞれの 群で大腿前面の筋体積と脚伸展パワーとの間に は，女性のみ若齢群および高龄群で有意な相関が みられ，男性では両年歯群での相関係数はそれと 比べて低く統計的に有意とはならなかった(Fig. 4).この結果は, 素早い力発揮様式における運動 単位の動員様式に男女間で差異があることを示唆 するものといえる。さらに，パワーの加齢による 低下率には男女間で差が見られないにもかかわら ず，単位筋体積当たりのパワーの加齢による低下 率は女性の方が男性より大きい傾向にあった。こ のことは, トルクの加䶡による低下率が女性より 男性で大きかったことを考えあわせると, 力発揮 速度や多関節運動での筋力発揮の調節機能におけ る加齢低下は，女性の方が男性より大きいという 可能性が示唆される.しかし，この点については 裏付けとなるデータは無く今後の検討が必要と考 えられる。

\section{要 約}

本研究では，20～30歳および60～70歳の男女 を対象に, 等尺性膝関節伸展トルク, 脚伸展パワー を測定し，その加齢変化および男女差について， 大腿前面の筋量との関係から検討した．その主な 結果は以下の通りであった。

1）トルクおよびパワーは男女ともに高齢群が若 齢群より有意に低值となり, 年齢群内では女 性の方が男性より低值であった。

2）単位筋体積当たりのトルクにおいても年齢差 はみられたが，性差はなかった。

3）単位筋体積当たりのパワーには年龄差および 性差がみられ，その年齢差はトルクにおける ものよりも大きかった。

以上の結果から，トルクよりもパワーにおいて 年齢差および性差は顕著にあらわれ，それらは筋 量における差だけでは説明できないことが示唆さ れた。

本原著に用いた研究成果の一部は, 平成11～16年度 に実施される文部科学省科学技術振興調整費(代表 村上和雄)により実施されたものである。ここに記し
て感謝する。

(受理日 平成15年 2 月 4 日)

\section{引用文 献}

1) McDonagh MJ, White MJ, Davies CT. Different effects of ageing on the mechanical properties of human arm and leg muscles. Gerontology (1984), 30. 49-54.

2) Fisher NM, Pendergast DR, Calkins EC. Maximal isometric torque of knee extension as a function of muscle length in subjects of advancing age. Arch. Phys. Med. Rehabil. (1990), 71, 729-34.

3) Bemben MG, Massey BH, Bemben DA, Misner JE, Boileau RA. Isometric muscle force production as a function of age in healthy 20 - to 74 -yr-old men. Med. Sci. Sports Exerc. (1991), 23, 1302-10.

4) Larsson L, Grimby G, Karlsson J. Muscle strength and speed of movement in relation to age and mus. cle morphology. J. Appl. Physiol. (1979), 46, 451-6.

5) Lindle RS. Metter EJ, Lynch NA, Fleg JL, Fozard JL, Tobin J, Roy TA, Hurley BF. Age and gender com. parisons of muscle strength in 654 women and men aged 20-93 yr. J. Appl. Physiol. (1997), 83, 1581-7.

6) Bassey EJ, Fiatarone MA, O'Neill EF, Kelly M, Evans WJ, Lipsitz LA. Leg extensor power and functional performance in very old men and women. Clin. Sci. (1992), 82, 321-7.

7) 川初清典. 脚筋の才了・速度 ・ パワー能力の年齢別 推移。体育学研究 (1974), 19, 201-206.

8）平野裕，，野口秋実，宮下充正. 加齢に伴う脚伸 展パワー值の変化とその評価. 体力科学 (1994), 43, 113-120.

9) Phillips SK, Bruce SA, Newton D, Woledge RC. The weakness of old age is not due to failure of muscle activation. J. Gerontol. (1992), 47, M45-9.

10) Madsen OR, Lauridsen UB, Hartkopp A, Sorensen $\mathrm{OH}$. Muscle strength and soft tissue composition as measured by dual energy $x$-ray absorptiometry in women aged 18-87 years. Eur. J. Appl. Physiol. Occup. Physiol. (1997), 75, 239-45.

11) Akima H, Kano Y, Enomoto Y, Ishizu M. Okada M, Oishi Y. Katsuta S, Kuno S. Muscle function in 164 men and women aged 20-84 yr. Med. Sci. Sports Exerc. (2001), 33, 220-6.

12) Trappe TA, Lindquist DM, Carrithers JA. Muscle-specific atrophy of the quadriceps femoris with aging. J. Appl. Physiol. (2001), 90, 2070-4.

13) Lexell J, Taylor CC, Sjostrom M. What is the cause of the ageing atrophy? Total number, size and proportion of different fiber types studied in whole vas. tus lateralis muscle from 15- to 83-year-old men. J. Neurol. Sci. (1988), 84, 275-94.

14) Klitgaard H, Mantoni M, Schiaffino S, Ausoni S. Gorza L, Laurent-Winter C. Schnohr P. Saltin B. 
Function, morphology and protein expression of ageing skeletal muscle: a cross-sectional study of elderly men with different training backgrounds. Acta. Physiol. Scand. (1990), 140, 41-54.

15) Miyatani M, Kanehisa H, Kuno S, Nishijima T, Fukunaga T. Validity of ultrasonograph muscle thickness measurements for estimating muscle volume of knee extensors in humans. Eur. J. Appl. Physiol. (2002), 86, 203-8.

16) Fukunaga T, Miyatani M, Tachi M, Kouzaki M, Kawakami Y, Kanehisa H. Muscle volume is a major determinant of joint torque in humans. Acta. Physiol. Scand. (2001), 172, 249-55.

17）福永哲夫. ヒトの絶対筋力. 杏林書院, 東京, (1978).

18) Sacks RD, Roy RR. A rchitecture of the hind limb muscles of cats: functional significance. J. Morphol. (1982), 173, 185-95.

19）大場陽登美, 安部孝. 腓腹筋内側頭の筋束長/筋長 比の個体差および性差. 体力科学 (1999)， 48, 910 .

20) Alkner BA, Tesch PA, Berg HE. Quadriceps EMGorce relationship in knee extension and leg press. Med. Sci. Sports Exerc. (2000), 32, 459-63.

21) Hakkinen K, Kraemer WJ, Newton RU. Muscle activation and force production during bilateral and unilateral concentric and isometric contractions of the knee extensors in men and women at different ages. Electromyogr. Clin. Neurophysiol. (1997), 37. 131-42.

22) Miller AE, MacDougall JD, Tarnopolsky MA, Sale DG. Gender differences in strength and muscle fiber characteristics. Eur. J. Appl. Physiol. Occup. Phy. siol. (1993), 66, 254-62.

23) Castro MJ, McCann DJ, Shaffrath JD, Adams WC. Peak torque per unit cross-sectional area differs between strength-trained and untrained young adults. Med. Sci. Sports Exerc. (1995), 27, 397-403.

24) Hakkinen K, Hakkinen A. Muscle cross-sectional area, force production and relaxation characteristics in women at different ages. Eur. J. Appl. Physiol. Occup. Physiol. (1991), 62, 410-4.

25) Trappe SW. Trappe TA, Lee GA, Costill DL. Calf muscle strength in humans. Int J Sports Med (2001), 22, 186-91.

26) Thorstensson A, Grimby G, Karlsson J. Forcevelocity relations and fiber composition in human knee extensor muscles. J. Appl. Physiol. (1976), 40, 12-6.

27) Ryushi T, Hakkinen K, Kauhanen H, Komi PV. Muscle fiber characteristics, muscle cross-sectional area and force production in strength athletes, physically active males and females. Scand. J. Sport Sci. (1988), 10, 7-15. 